\title{
AGEIST ATTITUDES AND THEIR ASSOCIATION WITH BURNOUT AND JOB SATISFACTION AMONG NURSING STAFF: A DESCRIPTIVE STUDY
}

Turkish Journal of Geriatrics

DOI: 10.31086/tjgeri.2018137963

2018:21 (1):25-32

- Serkan PEKÇETIN ${ }^{1}$

\section{Abstract}

Introduction: The various factors affecting burnout and job satisfaction among nursing staff have yet to be clearly identified. Accordingly, this study examines one of those potential factors, ageist attitudes, and its relation with burnout and job satisfaction among nursing home employees.

Materials and Method: This was a cross sectional multi-center study which was conducted in 2017. Ageism was evaluated using the Ageism Attitude Scale (subscales: restricting life of the elderly, positive ageism, and negative ageism); burnout level was evaluated using the Maslach Burnout Inventory (subscales: emotional exhaustion, depersonalization, and personal satisfaction); and job satisfaction was evaluated using the Short-Form Minnesota Satisfaction Questionnaire. Correlation between variables were analyzed Spearman Correlation test.

Results: Positive ageism was positively correlated with personal accomplishment and job satisfaction scores $(p<.05)$ and negatively correlated with depersonalization $(p<.05)$. ShortForm Minnesota Satisfaction Questionnaire scores were negatively correlated with emotional exhaustion and depersonalization and positively correlated with personal accomplishment variables $(p<.05)$.

Conclusion: Ageism negatively impacts not only elderly individuals but also the nursing staff who care for them. Educational programs to prevent ageism should be evaluated for efficiency and implemented if proven to be beneficial.

Keywords: Ageism; Job satisfaction; Nursing homes; Nursing staff
CORRESPONDANCE

Serkan PEKÇETIN

Trakya University, Faculty of Health Sciences

Department of Occupational Therapy

Edirne, Turkey

Phone: 905057579384

e-mail: serkanpekcetin@gmail.com

Received: 30/11/2017

Accepted: 04/02/2018

Trakya University, Faculty of Health Sciences Department of Occupational Therapy

Edirne, Turkey
ARAŞTIRMA

YAŞLI BAKIM PERSONELLERININ YAŞLI AYRIMCILIĞI İLE ILGILI TUTUMLARI İLE TÜKENME VE iş MEMNUNIYETI ARASINDAKI ILIŞKISININ INCELENMESII:TANIMLAYICI BIR ÇALIŞMA

\section{Öz}

Giriş: Yaşı bakım personellerinin tükenmişlik düzeyleri ve iş doyumlarını etkileyen faktörlerin pek çoğu henüz tam olarak tanımlanmamıştır. Dolayısıyla, bu çalışma bahsedilen potansiyel faktörlerden biri olan yaşlı ayrımcılığı tutumları ve bunun yaşlı bakım personelinin tükenmişlik ve iş doyumu ile ilișkisini incelemektedir.

Gereç ve Yöntem: Bu çalışma, 2017 yılında gerçekleştirilen kesitsel çok merkezli bir çalışmaydı. Yaşııık ile ilgili tutumlar Yaşı ıyrımcılığı Tutum Ölçeği (Alt boyutları: Yaşlının yaşamını sınıllandırma, pozitif tutumlar ve negatif tutumlar), tükenmişlik düzeyleri Maslach Tükenmişlik Envanteri (Alt Boyutları: Duygusal Tükenme, duyarsızlaşma ve kişisel başarı) ve iş doyumu Kısa Form Minnesota İş Doyum Ölçeği ile değerlendirildi. Değişkenler arasındaki ilişki Spearman Korelasyon testi ile incelendi.

Bulgular: Pozitif tutum puanları ile kişisel başarı ve iş doyumu puanları arasında pozitif yönde önemli bir ilişki $(p<.05)$ ve duyarsızlaşma ile negatif yönde önemli bir ilişki saptandı $(p<.05)$. Kısa Form Minnesota İş Doyum Ölçeği puanın duygusal tükenme ve duyarsızlaşma ile negatif yönde, kişisel başarı puanı ile pozitif yönde ilişkisi olduğu saptandı $(p<.05)$

Sonuç: Yaşılıık ile ilgili olumsuz tutumlar yanlızca yaşlıyı olumsuz etkilemez, aynı zamanda onların bakımını yapan bakım personelini de olumsuz etkileyebilir. Yaşılık ile ilgili olumsuz tutumların engellenmesi için eğitim programları etkinlik açısından değerlendirilmeli ve yararlı olduğu kanıtlanırsa uygulanmalıdır.

Anahtar sözcükler: Yaşlı ayrımcılığı; İs doyumu; Huzurevi; Yaşlı bakım personeli 


\section{INTRODUCTION}

The technological and scientific advances in the last century have greatly improved healthcare quality, thus extending average life expectancy and increasing the total number of elderly people worldwide (1). In Turkey, the elderly population increased by 17.1\% between 2011 and 2016 (2). In addition, other concurrent social changes such as decreasing birth rates, large-scale migration from rural to urban areas, and greater emphasis on women's professional opportunities have increased the need for nursing homes.

Physical and mental changes associated with the aging process increase the care needs of older adults (3), which are generally met by nursing staff. Caring for elderly individuals in nursing homes is emotionally and physically demanding, but it can also be a satisfying experience for nurses.

\section{Burnout in nursing staff}

Burnout, a term describing emotional, physical, and mental fatigue, is an insidious process. Maslach et al. described occupational burnout in terms of three dimensions: emotional exhaustion, characterized by workers' loss of motivation due to excessive demands and psychological stress at their job; depersonalization, which leads workers to respond to clients in negative, callous, and dehumanizing ways to create emotional distance from them; and lack of personal accomplishment, as workers negatively evaluate themselves and their profession (4). Burnout is important because of its association with loss of productivity, decreased ability to work, and low job satisfaction (5).

Previous studies have demonstrated that burnout is a key problem among nursing staff $(6,7)$. To the best of our knowledge, only one prior study has investigated burnout among Turkish nursing staff. In that study, contrary to most findings in the literature, Özçakar et al. revealed that Turkish nursing staff did not experience burnout. They cited the participants' young age and specific training for elderly care as possible explanations for this unexpected result
(8). Nursing staff burnout is affected by multiple factors, including work-related and personal factors (5). However, no studies have evaluated the relation between burnout and ageism.

\section{Ageism in nursing staff}

Ageism is defined as assumptions, prejudice, discrimination, and arbitrary decisions regarding an individual based on his or her age (9). Factors that may be related to ageism include the individual's own age, experiences, educational background, and cultural beliefs and values (10).

The presence of ageist attitudes can negatively impact the performance of healthcare providers who care for elderly individuals. A study investigating ageist attitudes among nursing students, nurses, and physicians in the Turkish context demonstrated that Turkish healthcare providers' attitudes toward older individuals were generally positive (11-13). However, to the best of our knowledge, no studies have evaluated ageist attitudes of Turkish nursing staff and its relation with occupational burnout and job satisfaction.

Therefore, this study fills this research gap by assessing ageist attitudes among Turkish nursing staff and determining the relation between ageism and burnout and job satisfaction. Furthermore, it examines the association between demographic variables and ageism attitudes, burnout, and job satisfaction among nursing staff.

\section{MATERIALS AND METHOD}

This study was performed at two public nursing homes for the elderly in Ankara, Turkey. The study protocol was approved by local ethic committee. All participants signed written informed consent forms prior to the study.

\section{Participants}

A total of 126 individuals were employed as care staff in these nursing homes. To be included in the study, employees must have been working 
for at least one year as nursing staff. To maximize the number of participants, all staff members who met the inclusion criteria were invited to participate. However, 11 nursing staff could not participate because they were on annual leave or shift leave, 9 others declined to participate, and 1 was excluded as the participant did not meet the inclusion criteria. Therefore, the final study sample comprised 105 nursing staff.

\section{INSTRUMENTS}

\section{Ageism Attitude Scale}

The Ageism Attitude Scale (AAS) was developed by Yılmaz and Terzioğlu in Turkey to evaluate the ageist attitudes of young people and adults. It comprised 23 items organized into 3 dimensions: 9 items on restricting life of the elderly, 8 on positive ageism, and 6 on negative ageism. Statements describing attitudes of positive ageism were scored as $5=$ completely agree, $4=$ agree, $3=$ unsure, $2=$ disagree, and $1=$ absolutely disagree; statements describing negative ageist attitudes were reversescored items. A higher score indicated positive ageism attitudes. Total scores ranged from 23 to 115 points overall, from 9 to 45 for restricting life of the elderly, from 8 to 40 for positive ageism, and from 6 to 30 for negative ageism. The intraclass correlation coefficient (ICC) for the scale was determined to be .80 (14).

\section{Maslach Burnout Inventory}

Maslach and Jackson developed the Maslach Burnout Inventory (MBI) to assess the frequency and intensity of perceived burnout among people in the helping professions. The Turkish version of the MBI was created in 1992. The MBI comprised 22 items organized into 3 subscales: emotional exhaustion (EE, 9 items), depersonalization ( $D, 5$ items), and personal accomplishment (PA, 8 items). Each item was scored on a five-point scale $(0=$ never, $1=$ several times a year, $2=$ several times a month, $3=$ several times a week, 4=every day). High EE or D scores and low PA scores indicated burnout. Reliability coefficients of the subscales were determined as follows: $\mathrm{EE}=.83, \mathrm{D}=.72$, and $\mathrm{PA}=.67$ (15).

\section{Short-Form Minnesota Satisfaction Question- naire}

The Short-Form Minnesota Satisfaction Questionnaire (SFMSQ) captures an employee's degree of satisfaction with his or her job. It comprised 20 items from the Long-Form Minnesota Satisfaction Questionnaire that best represent each of the 20 scales. Factor analysis of the 20 items resulted in two factors, intrinsic and extrinsic satisfaction. Intrinsic job satisfaction included factors such as activity, ability utilization, and achievement; extrinsic job satisfaction encompassed supervisoremployee relations, compensation, and company policies among other factors. Each item was rated on a five-point scale ( $5=$ very satisfied, $4=$ satisfied, $3=$ neither satisfied nor dissatisfied, 2=dissatisfied, $1=$ very dissatisfied). The general satisfaction score was the mean of all responses; intrinsic and extrinsic satisfaction scores were determined by calculating the mean of the relevant items (12 intrinsic and 8 extrinsic factors). High scores indicated higher levels of job satisfaction. Turkish SFMSO validity research was conducted and the Cronbach's alpha value was found as 0.87 (16).

\section{Statistical analyses}

The data were analyzed using SPSS version 22.0. Normality of data was analyzed using the Shapiro-Wilk test. Using the Mann-Whitney $U$ test, comparisons of the participants' AAS, MBI, and SFMSO values were made on the basis of four demographic variables (age, gender, education level, and marital status). Correlations between variables were analyzed using the Spearman correlation test. Spearman's correlation coefficient ( $r)$ values were classified as indicating "weak" (.00-.19), "mild" (.20-.39), "moderate" (.40-.59), "moderately strong" (.60-.79), and "strong" (.801.0) relations between variables. $P$ values less than .05 were considered to be statistically significant. 


\section{RESULTS}

The mean age of the participants was $36.40 \pm 6.80$ years (ranging from 20 to 51 years). The mean time of employment in the nursing home was $3.32 \pm 3.74$ years. The mean number of elderly people for whom the participants cared was $41.17 \pm 10.38$ per day.
Table 1 presents the demographic characteristics of the participants. The mean total AAS score was 82.76 \pm 7.44. Mean MBI scores were $9.69 \pm 6.04$ for $E E, 2.34 \pm 2.61$ for $D$, and $24.85 \pm 5.86$ for PA; the mean total SFMSQ score was $3.83 \pm .56$. Table 2 indicates the AAS, MBI, and SFMSQ values for the participants.

Table 1. Demographic characteristics of the participants (Ankara-Turkey, 2017) (n=105).

\begin{tabular}{lcr}
\hline Demographic variables & $\mathbf{n}$ & \% \\
\hline Sex & & 29.5 \\
Male & 31 & 70.5 \\
Female & 74 & \\
Marital status & 92 & 87.6 \\
Married & 10 & 9.5 \\
Single & 3 & 2.9 \\
Widowed & & \\
Education level & 46 & 43.8 \\
Primary school & 55 & 52.4 \\
High school & 4 & 3.8 \\
Associate degree & & \\
\hline
\end{tabular}

Table 2. Descriptive statistics for the AAS, MBI and SFMSQ scales (Ankara-Turkey, 2017).

\begin{tabular}{|c|c|c|c|c|c|}
\hline $\begin{array}{l}\text { Evaluation } \\
\text { Instruments }\end{array}$ & $\mathbf{n}$ & Minimum & Maximum & Mean & $\begin{array}{l}\text { Standard } \\
\text { deviation }\end{array}$ \\
\hline \multicolumn{6}{|l|}{ aAS } \\
\hline Restricting life of elderly & 105 & 25.00 & 45.00 & 34.86 & 3.95 \\
\hline Positive ageism & 105 & 16.00 & 40.00 & 30.52 & 4.32 \\
\hline Negative ageism & 105 & 10.00 & 25.00 & 17.44 & 3.55 \\
\hline $\begin{array}{l}\text { AAS total } \\
\text { MBI }\end{array}$ & 105 & 60.00 & 100.00 & 82.76 & 7.44 \\
\hline Emotional exhaustion & 105 & 0.00 & 27.00 & 9.69 & 6.04 \\
\hline Depersonalization & 105 & 0.00 & 14.00 & 2.34 & 2.61 \\
\hline $\begin{array}{l}\text { Personal accomplishment } \\
\text { SFMSO }\end{array}$ & 105 & 1.00 & 32.00 & 24.85 & 5.86 \\
\hline Intrinsic satisfaction & 105 & 2.25 & 5.00 & 3.91 & .54 \\
\hline Extrinsic satisfaction & 105 & 1.38 & 5.00 & 3.70 & .71 \\
\hline SFMSO Total & 105 & 2.15 & 5.00 & 3.83 & .56 \\
\hline
\end{tabular}

Note. AAS=Ageism Attitude Scale; MBI=Maslach Burnout Inventory; SFMSQ=Short Form Minnesota Satisfaction Questionnaire. 
No statistically significant differences were observed in AAS dimension scores according to participants' demographic characteristics. On the MBI scale, female participants had significantly higher EE scores than males $(p<.01)$. Participants who had high school or associate degrees had higher PA scores than those who graduated from primary school $(p<.05)$. Primary school graduates had higher extrinsic satisfaction scores on the SFMSQ than high school graduates and associate degree holders $(p<.05)$ (Table 3).
A mild positive correlation was observed between positive ageism and PA scores on the $\mathrm{MBI}$ scale and among intrinsic, extrinsic, and general satisfaction scores on the SFMSO. The $\mathrm{MBI}$ results revealed a mild negative correlation between positive ageism and $D$ scores, a mild positive correlation between general satisfaction scores and PA scores, and a moderate negative correlation between general satisfaction scores and EE and D scores. Table 4 presents the Spearman correlation analysis results.

Table 3. Comparision of AAS, MBI and SFMSQ scales according to demographic characteristics (Ankara-Turkey, 2017).

\begin{tabular}{|c|c|c|c|c|c|c|c|c|}
\hline & $\mathbf{R L}$ & PosA & NegA & EE & D & PA & IS & ES \\
\hline \multicolumn{9}{|l|}{ Gender } \\
\hline $\begin{array}{l}\text { Female } \\
(n=74)\end{array}$ & $34.90 \pm 4.10$ & $30.41 \pm 4.32$ & $17.83 \pm 3.53$ & $10.77 \pm 6.38$ & $2.55 \pm 2.90$ & $24.64 \pm 6.37$ & $3.89 \pm .52$ & $3.62 \pm .72$ \\
\hline \multirow[t]{2}{*}{$\begin{array}{l}\text { Male } \\
(n=31)\end{array}$} & $34.77 \pm 3.65$ & $30.77 \pm 4.37$ & $16.51 \pm 3.48$ & $7.12 \pm 4.20$ & $1.83 \pm 1.67$ & $25.35 \pm 4.46$ & $3.97 \pm .58$ & $3.88 \pm .65$ \\
\hline & p:.65 & p.:53 & p:.053 & p:.005** & p:.59 & p:.83 & p:.72 & p:.07 \\
\hline \multicolumn{9}{|l|}{ Age } \\
\hline $\begin{array}{l}\leq 35 \text { years } \\
(n=46)\end{array}$ & $35.21 \pm 4.01$ & $30.71 \pm 3.85$ & $16.86 \pm 3.60$ & $9.82 \pm 5.69$ & $1.93 \pm 2.28$ & $26.04 \pm 4.12$ & $3.97 \pm .47$ & $3.70 \pm .67$ \\
\hline $\begin{array}{l}>36 \text { years } \\
(n=59)\end{array}$ & $34.59 \pm 3.93$ & $30.37 \pm 4.68$ & $17.89 \pm 3.47$ & $9.59 \pm 6.34$ & $2.66 \pm 2.82$ & $23.93 \pm 6.81$ & $3.87 \pm .58$ & $3.70 \pm .74$ \\
\hline & p:.49 & p: .80 & p:.17 & p: .75 & p: .18 & p:.21 & p:.88 & p:.72 \\
\hline \multicolumn{9}{|l|}{$\begin{array}{l}\text { Marital } \\
\text { Status }\end{array}$} \\
\hline $\begin{array}{l}\text { Married } \\
(n=92)\end{array}$ & $34.92 \pm 3.99$ & $30.59 \pm 4.45$ & $17.56 \pm 3.65$ & $9.45 \pm 6.12$ & $2.39 \pm 2.69$ & $24.90 \pm 5.84$ & $3.92 \pm .53$ & $3.73 \pm .68$ \\
\hline \multirow[t]{2}{*}{$\begin{array}{l}\text { Single/ } \\
\text { Widowed } \\
(n=13)\end{array}$} & $34.46 \pm 3.84$ & $30.00 \pm 3.26$ & $16.61 \pm 2.69$ & $11.38 \pm 5.26$ & $2.00 \pm 2.04$ & $24.53 \pm 6.19$ & $3.83 \pm .56$ & $3.49 \pm .89$ \\
\hline & p: .92 & p: .52 & p: .30 & p: .19 & p: .79 & p: .89 & $p: .49$ & p: .43 \\
\hline \multicolumn{9}{|l|}{$\begin{array}{l}\text { Education } \\
\text { level }\end{array}$} \\
\hline $\begin{array}{l}\text { Primary } \\
\text { school } \\
(n=46)\end{array}$ & $34.34 \pm 4.18$ & $30.32 \pm 5.34$ & $17.34 \pm 3.49$ & $8.95 \pm 6.03$ & $2.06 \pm 2.45$ & $23.50 \pm 6.31$ & $3.90 \pm .50$ & $3.85 \pm .67$ \\
\hline \multirow{2}{*}{$\begin{array}{l}\text { High } \\
\text { school/ } \\
\text { Associate } \\
\text { degree } \\
(n=59)\end{array}$} & $35.27 \pm 3.76$ & $30.67 \pm 3.35$ & $17.52 \pm 3.63$ & $10.27 \pm 6.03$ & $2.55 \pm 2.73$ & $25.91 \pm 5.30$ & $3.92 \pm .57$ & $3.58 \pm .72$ \\
\hline & p:.20 & p:.96 & p:.78 & p:.17 & p:.30 & p:.024* & p:.92 & p:.019* \\
\hline
\end{tabular}

Note. $\mathrm{AAS}=$ Ageism Attitude Scale; $\mathrm{MBI}=$ Maslach Burnout Inventory; SFMSQ=Short Form Minnesota Satisfaction Questionnaire;

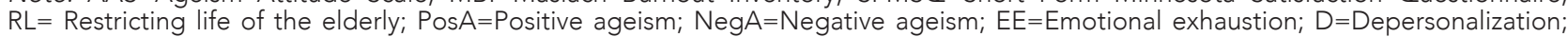
$\mathrm{PA}=$ Personal accomplishment; IS=Intrinsic satisfaction; $\mathrm{ES}=$ Extrinsic satisfaction. ${ }^{\star *} p<0.01$; ${ }^{*} p<0.05$. 
Table 4. Correlations among AAS, MBI and SFMSQ results (Ankara-Turkey, 2017).

\begin{tabular}{|c|c|c|c|c|c|c|c|c|c|}
\hline & 1 & 2 & 3 & 4 & 5 & 6 & 7 & 8 & 9 \\
\hline $\begin{array}{l}\text { Restricting } \\
\text { life of elderly }\end{array}$ & - & & & & & & & & \\
\hline Positive ageism & .105 & - & & & & & & & \\
\hline Negative ageism & $.250^{\star}$ & -.036 & - & & & & & & \\
\hline Emotional exhaustion & .068 & -.180 & -.058 & - & & & & & \\
\hline Depersonalization & -.086 & $-.318^{\star \star}$ & .026 & $.395^{\star \star}$ & - & & & & \\
\hline $\begin{array}{l}\text { Personal } \\
\text { accomplishment }\end{array}$ & .159 & $.213^{\star}$ & -.057 & -.147 & $-.388^{\star \star}$ & - & & & \\
\hline Intrinsic satisfaction & -.091 & $.289^{\star \star}$ & -.080 & $-.323^{\star \star}$ & $-.415^{\star \star}$ & $.243^{\star}$ & - & & \\
\hline Extrinsic satisfaction & -.201 & $.320 \star \star$ & -.098 & $-.487^{\star \star}$ & $-.450 * *$ & .120 & $.681^{\star \star}$ & - & \\
\hline SFMSO Total & -.163 & $.336^{\star \star}$ & -.114 & $-.449 * \star$ & $-.474^{\star \star}$ & $.212^{\star}$ & $.909 * \star$ & $.905^{\star \star}$ & - \\
\hline
\end{tabular}

Note. $\mathrm{AAS}=$ Ageism Attitude Scale; $\mathrm{MBI}=$ Maslach Burnout Inventory; SFMSQ=Short Form Minnesota Satisfaction Questionnaire. ${ }^{\star}$ Correlation is significant at the 0.05 level (2-tailed). ${ }^{\star *}$ Correlation is significant at the 0.01 level (2-tailed).

\section{DISCUSSION}

This study found that ageist attitudes among nursing staff were not related to their age, gender, education level, or marital status. However, ageist attitudes were associated with burnout levels and job satisfaction.

Elderly people in nursing homes spend much of their time with nurses while receiving assistance, with activities of daily living such as eating, bathing, dressing, and moving. Adverse changes in the attitudes and behavior of healthcare providers can impact quality of care $(17,18)$. Therefore, ageist attitudes, emotional burnout, and job satisfaction are critical issues among nursing home employees.

Previous studies have evaluated the presence of ageist attitudes among Turkish healthcare providers and nursing students. These studies have reported general tendencies toward positive ageism $(12,13)$.
Consistent with this literature, this study found a predominantly positive attitude toward the elderly among the nurses.

Polat et al. indicated that ageist attitudes among Turkish healthcare providers were not related to demographic characteristics such as age, gender, and education level (12). Usta et al. found a correlation between gender and positive ageism among Turkish nursing students. However, males constituted only $10 \%$ of the total study population in their study, indicating an important limitation that precludes the generalization of this result to the general population (11). The results of our study indicated that ageist attitudes were not associated with the demographic characteristics of the participants. The similar scores on positive ageism among Turkish healthcare providers and the lack of relation between ageist attitudes and demographic variables indicated that these 
attitudes may be primarily influenced by cultural factors. This interpretation is supported by Kydd et al., who reported differences in the ageist attitudes of healthcare personnel in three countries (19).

Studies have reported that nurses have a high risk of burnout, which may affect the quality of care that they provide $(20,21)$. However, the study by Özçakar et al. indicated lower levels of burnout among Turkish nursing staff compared with other studies in the literature. Similarly, we found that the nurses in our study experienced low burnout levels. These contradictory findings may stem from the differences in occupational context between the studies.

This study suggested that female participants experience more burnout than males, a finding consistent with that of Özçakar et al. (8). In contrast, Kendelman et al. reported that gender was not a risk factor for burnout among caregivers (6). Numerous earlier studies have demonstrated higher burnout levels among Turkish female professionals than among their male colleagues $(22,23)$. Turkish women have more household and child-care responsibilities compared with their male counterparts, and this factor may contribute to their higher risk of burnout.

lecovic and Avivi examined ageist attitudes among nurses in long-term care centers. They found that ageism was related with depersonalization and personal accomplishment but not with emotional exhaustion (24). Our findings are similar

\section{REFERENCES}

1. He W, Goodkind D, Kowal PR. An aging world: 2015 United States Census Bureau. U.S. Government Publishing Office, Washington DC 2016, pp 1-15.

2. Press Releases of Turkish Statistical Institute; Elderly Statistic, 2016 [Internet] Available from: http:// www.tuik.gov.tr/PreHaberBultenleri.do?id=24644. Accessed:01.10.2017. (in Turkish).

3. Solanki SL, Singhal G, Mishra N, Meharda B. Health problems of elderly: a challenge for care. Int J Cur Res Rev 2015;7(5):38-42. to those results; however, the correlations that we observed with depersonalization and personal accomplishment parameters were not as strong as those reported by lecovic and Avivi. In this study, no direct relation was observed between ageism and burnout; however, work-related parameters, the role of which was not assessed in this study, may significantly impact burnout among nursing staff.

The relation between burnout and job satisfaction among geriatric care workers has been previously demonstrated (25). As expected, our findings are consistent with those of a prior study. Overall, we believe that this is the first study to show a relation between ageist attitudes and job satisfaction among nursing staff. However, we cannot conclude that nursing staff should receive education or training aimed at preventing the incidence of ageism because the evidence of the effectiveness of such training is insufficient. Further prospective studies should be conducted to determine whether educational interventions can reduce ageist attitudes.

This study has two important limitations. First, it was performed in only two nursing homes, limiting the generalizability of the findings. Second, the scope of our analysis did not include all organizational and personal variables that may affect ageism, burnout, and job satisfaction. However, despite these limitations, this study demonstrates that ageism negatively impacts not only elderly individuals receiving care but also nursing staff.

4. Maslach C, Schaufeli WB, Leiter MP. Job burnout. Ann Rev Psychol 2001;52(1):397-422. (PMID:11148311).

5. Westermann C, Kozak A, Harling M, Nienhaus A. Burnout intervention studies for inpatient elderly care nursing staff: Systematic literature review. Int J Nurs Stud 2014;51(1):63-71. (PMID:23273537).

6. Kendelman N, Mazars T, Levy A. Risk factors for burnout among caregivers working in nursing homes. 2018 Jan;27(1-2):e147-e153. (PMID:28543882). 
7. Sanchez S, Mahmoudi R, Moronne I, Camonin D, Novella JL. Burnout in the field of geriatric medicine: Review of the literature. Eur Geriatr Med 2015;6(2):175-83.

8. Özçakar N, Kartal M, Dirik G, Tekin N, Güldal D. Burnout and relevant factors in nursing staff: What affects the staff working in an elderly nursing home? Turkish Journal of Geriatrics 2012;15(3):266-72.

9. Kydd A, Fleming A. Ageism and age discrimination in health care: Fact or fiction? A narrative review of the literature. Maturitas 2015;81(4):432-38. (PMID:26044073).

10. Akdemir N, Cınar Fl, Gorgulu U. Perception of ageing and ageism. Turkish Journal of Geriatrics 2007;10(4):215-22. (In Turkish).

11. Usta $Y Y$, Demir $Y$, Yonder $M$, Yildiz A. Nursing students' attitudes toward ageism in Turkey. Arch Gerontol Geriatr 2012;54(1):90-93. (PMID:21353316).

12. Polat U, Karadag A, Ulger Z, Demir N. Nurses' and physicians' perceptions of older people and attitudes towards older people: Ageism in a hospital in Turkey. Contemp Nurs 2014;48(1):88-97. (PMID:25410199).

13. Özdemir Ö, Bilgili N. Attitudes of Turkish nursing students related to ageism. J Nurs Res 2016;24(3):21116. (PMID:26998768).

14. Vefikuluçay YD, Terzioglu F. Development and psychometric evaluation of ageism attitude scale among the university students. Turkish Journal of Geriatrics 2011;14(3):259-68.

15. Ergin C. The norms of Maslach Burnout Inventory in Turkish Medical Staff. Journal of 3P. 1996;4(1):28-33. (In Turkish).

16. Köroğlu Ö. Determination of the relationship between the levels of intrinsic and extrinsic job satisfaction with level of general job satisfaction: an investigation on tour guides. DUJ 2012;13(2):275-89. (in Turkish).
17. Wallace JE, Lemaire JB, Ghali WA. Physician wellness: A missing quality indicator. Lancet 2009;374(9702):1714-21. (PMID:19914516).

18. Nantsupawat A, Nantsupawat R, Kunaviktikul W, Turale S, Poghosyan L. Nurse burnout, nursereported quality of care, and patient outcomes in Thai hospitals. J Nurs Sch 2016;48(1):83-90. (PMID:26650339).

19. Kydd A, Touhy T, Newman D, Fagerberg I, Engstrom G. Attitudes towards caring for older people in Scotland, Sweden and the United States. Nurs Older People 2014;26(2):33-40. (PMID:24576249).

20. Cocco E, Gatti M, Lima C, Camus V. A comparative study of stress and burnout among staff caregivers in nursing homes and acute geriatric wards. Int J Geriatr Psychiatry 2003;18(1):78-85. (PMID:12497560).

21. Cañadas-De la Fuente GA, Vargas C, Luis CS, García I, Cañadas GR, Emilia I. Risk factors and prevalence of burnout syndrome in the nursing profession. Int J Nurs Stud 2015;52(1):240-49. (PMID:27623931).

22. Anıl M, Yurtseven A, Yurtseven I. et al. The evaluation of burnout and job satisfaction levels in residents of pediatrics. Turk Pediatri Ars 2017;52(2):66-71. (PMID:28747836).

23. Kaptanoglu AY, Demir T. Examining job satisfaction among perfusionists: A brief report from Istanbul. J Pak Med Assoc 2013;63(9):1157-62. (PMID:24601197).

24. lecovich E, Avivi M. Agism and burnout among nurses in long-term care facilities in Israel. Aging Ment Health 2017;21(3):327-35. (PMID:26496232).

25. Rouxel G, Michinov E, Dodeler V. The influence of work characteristics, emotional display rules and affectivity on burnout and job satisfaction: A survey among geriatric care workers. Int J Nurs Stud 2016;62:81-89. (PMID:27468116). 